\title{
ON DENUDATION RATES IN KARST
}

\section{O HITROSTI DENUDACIJE NA KRASU}

\author{
Franci GABROVŠEK ${ }^{1}$
}

\begin{abstract}
UDC 551.331.24:551.44

Franci Gabrovšek: On denudation rates in Karst

Paper presents a simple mathematical model, which enables study of denudation rates in karst. A vertical flow of water which is uniformly infiltrated at the surface is assumed. Denudation rate is calculated from the time needed to remove certain thickness of rock. This is done concretely on a limestone block dissected by a vertical array of fractures. It is shown that denudation rate increases with the thickness of removed layer and approaches an upper limit which is defined by the maximum denudation equations, which are based on assumption that all dissolution potential is projected into a surface lowering.

Keywords: karst, denudation rate, limestone dissolution, mathematical model.
\end{abstract}

Izvleček

UDK 551.331.24:551.44

Franci Gabrovšek: O hitrosti denudacije na Krasu

$\mathrm{V}$ prispevku predstavim enostaven matematični model s katerim raziskujem dinamiko zniževanja kraškega površja. Predpostavim enakomerno napajanje s površja in vertikalno pronicanje vode. Denudacijsko stopnjo izračunam iz časa, ki je potreben za odstranitev določene debeline kamninskega sloja. Konkretno to naredim na primeru apnenca v katerem se voda pretaka v sistemu vertikalnih razpok. Hitrost denudacije narašča $\mathrm{z}$ debelino odstranjene plasti in doseže zgornjo mejo, ki je določena $z$ enačbami, ki temeljijo na predpostavki, da se celoten korozivni potencial vode manifestira v zniževanju površja. Ključne besede: kras, denudacijska stopnja, raztapljanje apnenca, matematični model.

\section{INTRODUCTION}

Uniform lowering or surface denudation is a dominant karstification process (Dreybrodt, 1988; Ford \& Williams, 1989; White, 1988). The denudation rate is defined as the rate $\left(\mathrm{LT}^{-1}\right)$ of lowering of a karst surface due to the dissolution of bedrock. A common approach used to estimate the denudation rate is based on the presumed equilibrium concentration (or hardness) and the amount of water which infiltrates into the subsurface. It is summarized in the famous Corbel's equation (Corbel, 1959):

$$
D_{C}(m / M a)=\frac{(P-E) H}{1000 \cdot \rho} f
$$

The infiltrated water in $\mathrm{mm} / \mathrm{y}$ is the difference between precipitation $\mathrm{P}$ and evapotranspiration $\mathrm{E}$. $\mathrm{H}$ is the equilib- rium concentration (Hardness) in $\mathrm{mg} / \mathrm{L}$ of dissolved rock, $\rho$ is the density of limestone in $\mathrm{g} / \mathrm{cm}^{3}, \mathrm{f}$ denotes the portion of soluble mineral in the rock, which will be 1 in this paper. The factor 1000 corrects for the mixture of units used in the equation.

There are more general equations of this kind like that of White (1984, this issue). For a Limestone terrain in a temperate climate all these equations give denudation rate of the order of several tens of meters per million years. Similar results are obtained from flow and concentration measurements in rivers which drain a known catchment area. From the measured data the total rock volume removed from the area in a given time period can be calculated. Dividing the removed volume by the surface of the area and the time interval gives the denudation rate.

${ }^{1}$ Karst Research Institute ZRC SAZU, Postojna, Slovenia, e-mail: gabrovsek@zrc-sazu.si

Received/Prejeto: 01.02.2007 
Eq.1 implies that all dissolution capacity of water is used in the rock column, i.e. the solution at the exit of rock block is close to saturation. Among the many assumptions behind such estimations of the denudation rate I will address two of which at least one must be valid:
1. Most of the dissolution occurs close to the surface, i.e. within epikarst.

2. In the long term, the dissolution at depth is integrated into a surface denudation.

It is the intention of this paper to theoretically validate "maximum denudation" approach.

\section{SURFACE LOWERING AND THE VOLUME OF DISSOLVED ROCK}

Dissolution of any rock is not instantaneous, but proceeds at some finite rates. In conditions of diffuse infiltration through the karst surface and prevailing vertical flow, the concentration of dissolved rock in the infiltrating water will normally increase with the depth as schematically shown by color intensity in Fig.1.

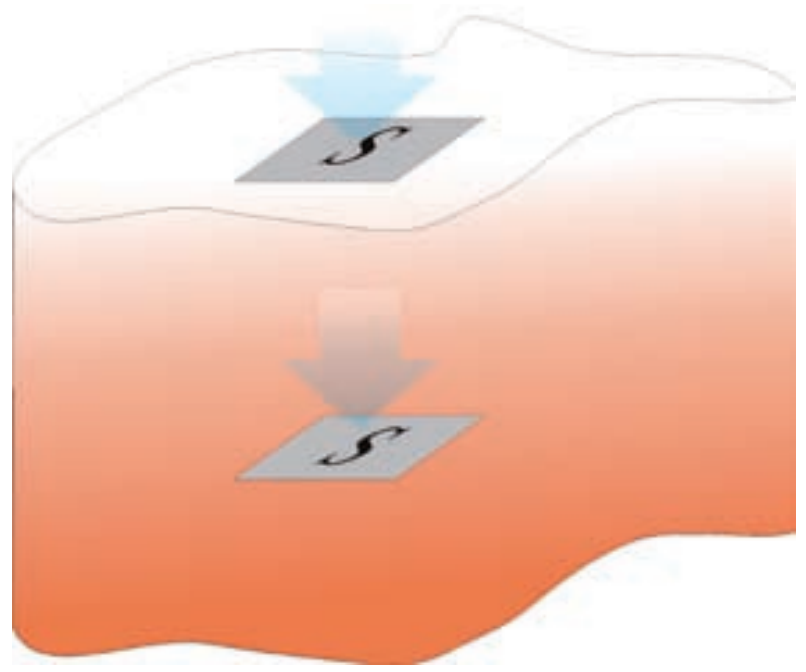

Fig. 1. Section of a terrain with a uniform surface infiltration of aggressive solution and prevailing vertical flow. Color intensity denotes that the concentration of dissolved rock increases with depth.

Fig. 2 presents point at some depth $\mathrm{z}$ below the surface. The volume $\Delta \mathrm{V}$ of rock dissolved per unit surface area $\mathrm{S}$ in time $\Delta \mathrm{t}$ between the surface and the point is given by

$$
\Delta V / S=c(z) \cdot q \cdot \Delta t / \rho
$$

where $c(z)$ is the concentration of dissolved rock $\left[M / L^{3}\right]$ at the depth $\mathrm{z}, \mathrm{q}$ is the infiltration rate at the surface $\left[\mathrm{L}^{3} /\right.$ $\left.\left(\mathrm{L}^{2} \mathrm{~T}\right)\right]$ and $\rho$ is the density of the rock $\left[\mathrm{M} / \mathrm{L}^{3}\right]$.

Due to the surface lowering, the depth of the point is decreasing according to $\mathrm{z}(\mathrm{t})=\mathrm{z}_{0}-\mathrm{D} \cdot \mathrm{t}$, where $\mathrm{z}_{0}$ is the

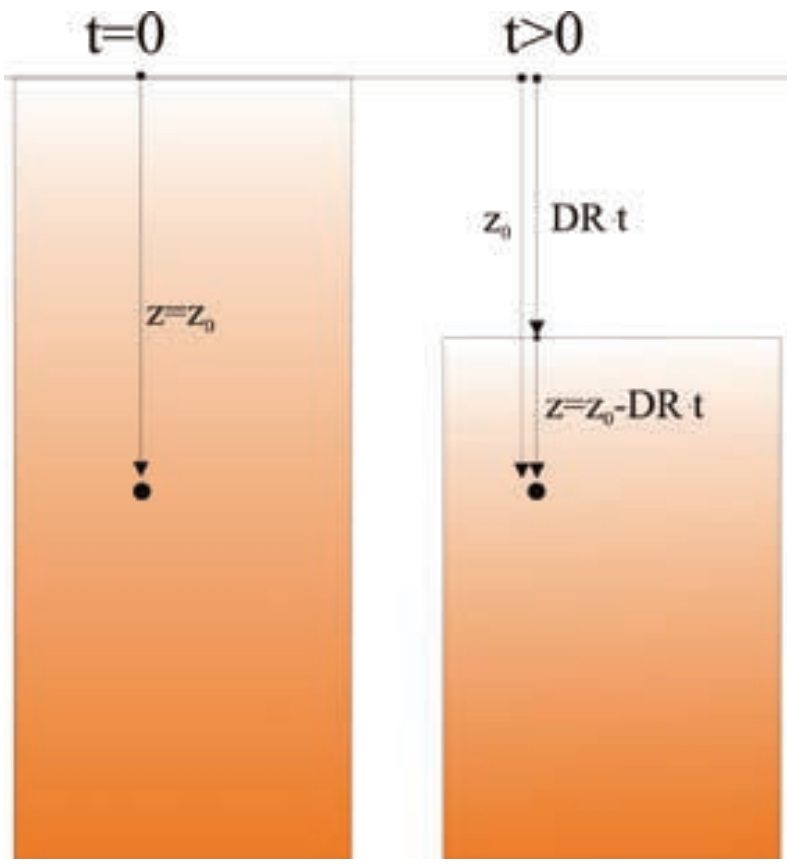

Fig. 2: Idealized profile through the rock column at time $t=$ 0 (left) and $t>0$ (right). The depth of the point which is at $z_{0}$ decreases in time due to the surface lowering.

depth at $t=0$ and $D$ is the denudation rate (Fig. 2). The volume of dissolved rock per surface area in time $\mathrm{T}$ above the point is then given by:

$$
\Delta V / S(T)=\frac{q}{\rho} \int_{0}^{T} c(z(t)) d t=\frac{q}{\rho} \int_{0}^{T} c\left(z_{0}-D \cdot t\right) d t \quad 3
$$

Introducing a new variable $\mathrm{z}=\mathrm{z}_{0}-\mathrm{D} \cdot \mathrm{t}$ into the right hand integral in Eq. 3 gives:

$$
\frac{\Delta \mathrm{V}}{\mathrm{S}}(\mathrm{T})=\frac{\mathrm{q}}{\mathrm{D} \cdot \rho_{\mathrm{z}_{0}-\mathrm{DR} \cdot \mathrm{T}}} \int_{\mathrm{z}_{0}} \mathrm{c}(\mathrm{z}) \mathrm{dz}
$$


The complete volume of rock initially above $z_{0}$ is $z_{0} \cdot S$. To remove this volume a time $T_{D}$ is needed, where $z_{0}$ $=\mathrm{D} \cdot \mathrm{T}_{\mathrm{D}}$. Using all this in Eq. 4, we obtain:

$$
\begin{gathered}
z_{0}=\frac{q}{D \cdot \rho} \int_{0}^{z_{0}} c(z) d z=\frac{q \cdot T_{D}}{z_{0} \cdot \rho} \int_{0}^{z_{0}} c(z) d z \\
\frac{z_{0}}{T_{D}}=D=\frac{q}{z_{0} \cdot \rho} \int_{0}^{z_{0}} c(z) d z
\end{gathered}
$$

As given, $\mathrm{D}$ is an average denudation rate, calculated from the time $T_{D}$ needed to remove a layer of thickness $\mathrm{z}_{0}$ from the rock column with initial a uniform porosity distribution in vertical direction. If a rock layer has a finite thickness, $\mathrm{z}_{0}$ can be taken as the layer thickness, $T_{D}$ the time needed to remove the com- plete layer and $\mathrm{D}$ an avarege denudation rate. It is easy to see that if the solution quickly attains equilibrium Eq. 6 gives maximum denudation rates:

$$
\mathrm{D}=\frac{\mathrm{q} \cdot \mathrm{c}_{\mathrm{eq}}}{\mathrm{z}_{0} \cdot \rho} \int_{0}^{\mathrm{z}_{\mathrm{o}}} \mathrm{dz}=\frac{\mathrm{q} \cdot \mathrm{c}_{\mathrm{eq}}}{\rho}=\mathrm{D}_{\mathrm{C}}
$$

If this is not the case $\mathrm{D}$ will be below $\mathrm{D}_{c}$, since integral with $\mathrm{c}_{\mathrm{eq}}$ is maximal. In this case we rewrite Eq. 6 as:

$$
\mathrm{D}=\frac{\mathrm{D}_{\mathrm{c}}}{\mathrm{c}_{\mathrm{eq}}} \cdot \frac{1}{\mathrm{z}_{0}} \int_{0}^{\mathrm{z}_{\mathrm{o}}} \mathrm{c}(\mathrm{z}) \mathrm{dz}=\frac{\overline{\mathrm{c}}\left[0, \mathrm{z}_{0}\right]}{\mathrm{c}_{\mathrm{eq}}} \mathrm{D}_{\mathrm{C}}
$$

With increasing layer thickness an average concentration within the layer increases and average denudation rates approach maximal.

\section{CALCULATION OF THE CONCENTRATION PROFILE}

The results given so far are valid for any "natural" $c(z)$. To obtain some quantitative results we revert to a special case where the calcite aggressive water is infiltrating into a vertical fracture network. Therefore we need to couple the rate equation for limestone and flow of laminar film down a vertical fracture wall.

\section{LIMESTONE DISSOLUTION RATES}

Recently Kaufmann \& Dreybrodt (2007) published the corrected rate equation with two linear regions and a non-linear region of dissolution kinetics:

$$
R=\left\{\begin{array}{l}
\alpha_{1}\left(0.3 c_{e q}-c\right) c<0.3 c_{e q} \\
\alpha_{2}\left(c_{e q}-c\right) 0.3 c_{e q}<c<0.9 c_{e q} \\
\beta\left(c_{e q}-c\right)^{n} \quad c>0.9 c_{e q}
\end{array}\right.
$$

The kinetic constants and rate orders are derived from theoretical and experimental results (Buhmann \& Dreybrodt, 1985; Dreybrodt, 1988; Eisenlohr et al., 1999; Kaufmann \& Dreybrodt, 2007). Values depend on the temperature, $\mathrm{p}_{\mathrm{CO} 2}$ and laminar layer thickness and are given in Kaufmann \& Dreybrodt (2007). We will use $\alpha_{1}=$ $3 \cdot 10^{-4} \mathrm{~cm} / \mathrm{s}$ and $\alpha_{2}=8 \cdot 10^{-6} \mathrm{~cm} / \mathrm{s}$, values which are valid at $10^{\circ} \mathrm{C}$ for the open system dissolution (Kaufmann \& Dreybrodt, 2007). Nonlinear kinetics will not be discussed here. It is valid close to equilibrium and does not change the results substantially. $\mathrm{c}_{\mathrm{eq}}$ depends on the $\mathrm{p}_{\mathrm{CO} 2}$, temper- ature, the presence of the foreign ions and the nature of the system where dissolution proceeds (open, closed, intermediate) (Appelo \& Postma, 1993; Dreybrodt, 1988). The calcium equilibrium concentration normally takes values between $0.5 \mathrm{mmol} / \mathrm{l}-3 \mathrm{mmol} / \mathrm{l}$, which in terms of dissolved calcite means 50-300 mg/l .

\section{LAMINAR FLOW DOWN A SMOOTH VERTICAL WALL}

Only rough assumptions can be made about the flow regime of infiltrated water. We assume a laminar film flow down the walls of vertical fractures. The velocity of such film is given by (Bird et al., 2002):

$$
\overline{\mathrm{v}}=\frac{\mathrm{g} \delta^{2}}{3 v}
$$

where $\delta$ is the film thickness, g gravitational acceleration and $v$ the kinematic viscosity. More suitable master variable is a flow density along the fracture walls $\mathrm{q}_{\mathrm{f}}\left(\mathrm{cm}^{2} / \mathrm{s}\right)$. Applying $\mathrm{q}_{\mathrm{f}}=\overline{\mathrm{v}} \delta$ we get:

$$
\delta=\sqrt[3]{\frac{3 \mathrm{q}_{\mathrm{f}} v}{\mathrm{~g}}} \text { and } \overline{\mathrm{v}}=\mathrm{q}_{\mathrm{f}}{ }^{2 / 3}\left(\frac{\mathrm{g}}{3 v}\right)^{1 / 3}
$$




\section{THE COUPLING OF FLOW AND DISSOLUTION}

To get the evolution of a concentration in a falling film, the mass balance for dissolved calcite must be coupled to the rate laws given in Eq. 9. In a small volume of water film with thickness $\delta$, width $b$, length $d z$ and concentration $c$, the mass balance requires:

$$
\begin{aligned}
& A \alpha_{1}\left(c_{a p p}-c\right) d t=V d c=A \delta d c ; c<0.3 c_{e q} \\
& A \alpha_{2}\left(c_{e q}-c\right) d t=V d c=A \delta d c ; 0.3 c_{e q}<c<0.9 c_{e q}
\end{aligned}
$$

where $A$ is the surface of the water rock contact $(b \cdot d z)$. Integration of Eq. 12 gives the evolution of concentration in time as the film flows down the fracture wall:

$$
c(t)=\left\{\begin{array}{l}
0.3 c_{e q}\left(1-e^{-t / \tau_{1}}\right) ; c<0.3 c_{e q} \\
c_{e q}\left(1-0.7 \mathrm{e}^{-t / \tau_{2}}\right) ; 0.3 c_{e q}<c<0.9 c_{e q}
\end{array}\right.
$$

where $\tau_{\mathrm{i}}=\delta / \alpha_{\mathrm{i}}$. Note that $\tau_{1}$ is more than an order of magnitude smaller than $\tau_{2}$. The time domain can easily be converted into the space domain using $\mathrm{z}=\overline{\mathrm{v}} \cdot \mathrm{t}$ and $\mathrm{q}_{\mathrm{f}}=\overline{\mathrm{v}} \cdot \delta$

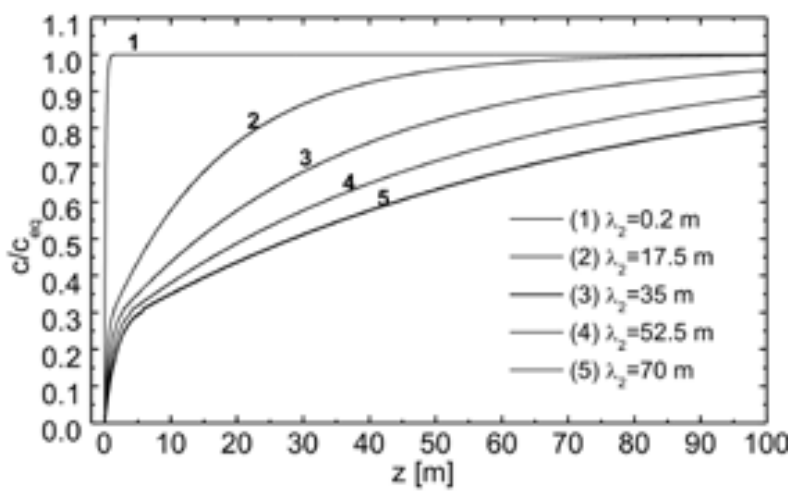

Fig.3: Concentration profile in a film flowing down a smooth vertical fracture and dissolving limestone walls. Values of $\lambda 2$ are calculated from the fracture flow density obtained if the fracture spacing is $1 \mathrm{~m}$ and infiltration intensity is $0.114 \mathrm{~mm} / \mathrm{h}, 10 \mathrm{~mm} / \mathrm{h}$, $20 \mathrm{~mm} / \mathrm{h}, 30 \mathrm{~mm} / \mathrm{h}$ and $40 \mathrm{~mm} / \mathrm{h}$ for curves $1-5$ respectively.

$$
c(z)=\left\{\begin{array}{l}
0.3 c_{e q}\left(1-e^{-z / \lambda_{1}}\right) ; c<0.3 c_{e q} \\
c_{e q}\left(1-0.7 e^{-z / \lambda_{2}}\right) ; 0.3 c_{e q}<c<0.9 c_{e q}
\end{array}\right.
$$

where $\lambda_{\mathrm{i}}=\mathrm{q}_{\mathrm{f}} / \alpha_{\mathrm{i}}$. Fig. 3 presents the evolution of saturation ratio $\mathrm{c}(\mathrm{z}) / \mathrm{c}_{\mathrm{eq}}$ for different $\lambda_{2}$. For most reasonable scenarios, the first linear kinetics is active only close to the surface. Therefore, it will be integrated directly into the surface lowering (i.e. $\mathrm{c}(\mathrm{z}=0)=0.3 \mathrm{c}_{\mathrm{eq}}$ ).

\section{SATURATION LENGTH $\lambda$ AND THE FRACTURE FLOW DENSITY}

Saturation length $\lambda_{2}$ controls the vertical evolution of concentration profile. It depends on the kinetic constant and the fracture flow density. To estimate the latter we assume that the rain falling to the surface with an intensity $\mathrm{q}$ is evenly infiltrated into a regular grid of fractures as shown on Fig. 4. The flow density in each fracture is proportional to the ratio between the surface of the infiltration area and the total breadth of the fractures draining the area. In a regular grid of fractures with fracture spacing $d$ we obtain:

$$
q_{f}=N \cdot q \cdot d
$$

Fig. 4: Rain falling with intensity $q$ [LT-1] is uniformly distributed into the fractures with flow density of [LT-1] according to Eq.15.

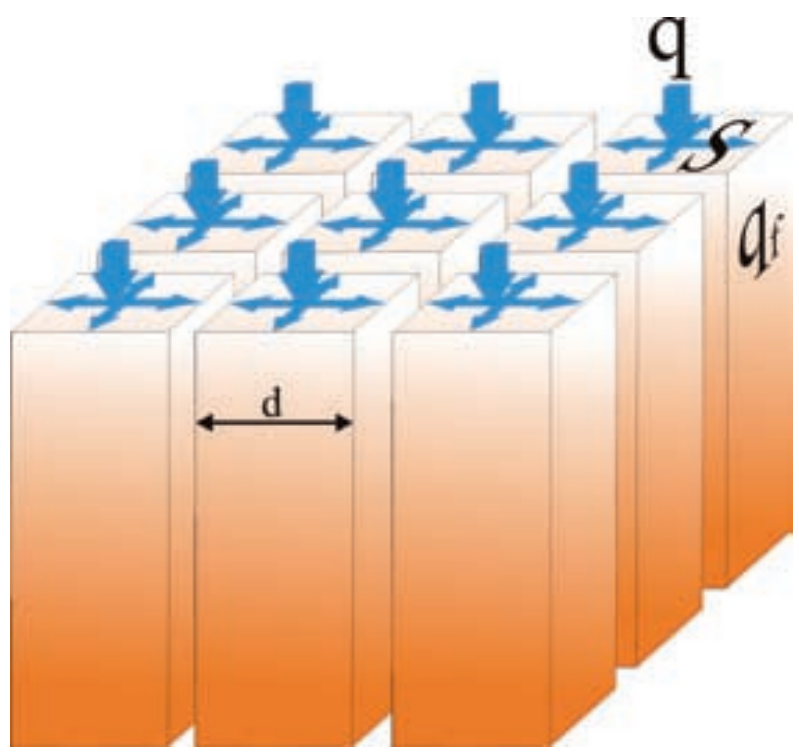


where $\mathrm{N}$ depends on the geometry of fracture grid (e.g. $1 / 2$ for a series of parallel fractures and $1 / 4$ for a square grid).

For thin films $(\delta<0.005 \mathrm{~cm})$ the rates are controlled by conversion of $\mathrm{CO}_{2}$ into $\mathrm{H}^{+}$and $\mathrm{HCO}_{3}$ - and therefore increase linearly with film thickness. Infiltration intensity below $3 \mathrm{~mm} / \mathrm{h}$ into a series of fractures with $\mathrm{d}=100 \mathrm{~cm}$ produces film thicknesses below $0.005 \mathrm{~cm}$. Extremely low infiltration intensities $(<1 \mathrm{~mm} / \mathrm{h})$ and fracture spacing in the range of few centimeters result in film thicknesses in the order of $0.001 \mathrm{~cm}$. This reduces the kinetic con- stant $\alpha$ approximately by a factor of 5 . For thin films, the film thickness and $\alpha$ decrease with $\mathrm{q}_{\mathrm{f}}^{1 / 3}$. Consequently $\lambda_{2}$ is proportional to the $\mathrm{q}_{\mathrm{f}}^{2 / 3}$. This has limited consequences for the dissolved volume and denudation rate discussed in the next section.

In the early stages, the fracture flow is not expected to be in the form of a free surface film, but full fracture flow instead. The saturation lengths in that case would be smaller than those derived here. The evolution of such fractures is given in Dreybrodt et al. (2005).

\section{RESULTS AND DISCUSSION}

Inserting the concentration profile from Eq. 14 (second linear region only) into Eq. 7 gives:

$$
\begin{aligned}
\mathrm{D} & =\frac{\mathrm{q} \cdot \mathrm{c}_{\mathrm{eq}}}{\rho} \int_{0}^{\mathrm{z}_{0}}\left(1-0.7 \mathrm{e}^{-\mathrm{z} / \lambda_{2}}\right) \mathrm{dz}= \\
& =\frac{\mathrm{qc}_{\mathrm{eq}}}{\rho}-\frac{0.7 \mathrm{qc}_{\mathrm{eq}}}{\rho} \int_{0}^{z_{0}} \mathrm{e}^{-\mathrm{z} / \lambda_{2}} \mathrm{dz}= \\
& =\mathrm{D}_{\mathrm{c}}-0.7 \cdot \mathrm{D}_{\mathrm{c}} \cdot \frac{\lambda_{2}}{\mathrm{z}_{0}} \cdot\left(1-\mathrm{e}^{-\mathrm{z}_{0} / \lambda_{2}}\right)
\end{aligned}
$$

Although it is a matter of a definition, the average denudation rate given in Eqs. 8 and 16 are not exactly what we are after. What we look for is the actual lowering of karst surface, which is given by $d z_{0} / d T_{D}$. We will not go into mathematical details of derivation, but instead discuss its consequences on a plot of $z_{0}(T D)$. Note that the $\mathrm{z}_{0}\left(\mathrm{~T}_{\mathrm{D}}\right)$ has no explicit form, but its inverse function does:

$$
\mathrm{T}_{\mathrm{D}}\left(\mathrm{z}_{0}\right)=\frac{\mathrm{z}_{0}}{\mathrm{D}_{\mathrm{c}}-0.7 \cdot \mathrm{D}_{\mathrm{C}} \cdot \frac{\lambda_{2}}{\mathrm{z}_{0}}\left(1-\mathrm{e}^{-\mathrm{z}_{0} / \lambda_{2}}\right)}
$$

We will demonstrate the results on a characteristic data for a moderate climate with $\mathrm{I}=1000 \mathrm{~mm} / \mathrm{y}$ and relatively bare karst area with $\mathrm{c}_{\mathrm{eq}}=1 \mathrm{mmol} / \mathrm{l}$ or $\mathrm{H}=100 \mathrm{mg} / \mathrm{L}$. For $\rho=2.5 \mathrm{~g} / \mathrm{cm}^{3}$. D for this case is $40 \mathrm{~m} / \mathrm{Ma}$. We assume that the rain infiltrates into a parallel set of fractures with spacing $\mathrm{d}=1 \mathrm{~m}$.
Fig. 5a shows $z_{0}\left(T_{D}\right)$ for four different saturation lengths arising from different infiltration intensities. Yearly infiltration is $1000 \mathrm{~mm} / \mathrm{y}$ for all curves. Therefore, the time period of dissolution is inversely proportional to the infiltration intensity. Dashed line shows the uniform lowering by $\mathrm{D}_{\mathrm{C}}$. We wee that all lines become practically parallel to maximum denudation line for $z_{0}>2 \lambda_{2}$. The actual denudation rate becomes "maximal" when the removed thickness is larger than $2 \lambda_{2}$. This is about the depth where the concentration reaches $90 \%$ of saturation. The slope of the dotted lines presents the averaged denudation rates for curve with $\lambda_{2}=70 \mathrm{~m}$.

Fig. 5b shows the averaged rate for the same scenarios as Fig. 5a. Red dashed red curve clearly shows the fast approach of the actual rate to maximal for $\lambda_{2}=52.5 \mathrm{~m}$.

Another interesting conclusion can be made from Fig. 5a. Different saturation lengths $\lambda$ can also arise from different fracture spacing (see Eq. 15 for qf). If we imagine a region with high fracture density within a region of low fracture density, the first will initially be denuded faster, but latter on both actual rates will become the same. Therefore the difference made at the onset will stay projected in the surface. This is shown by the double arrow between lines 3 and 4 . 

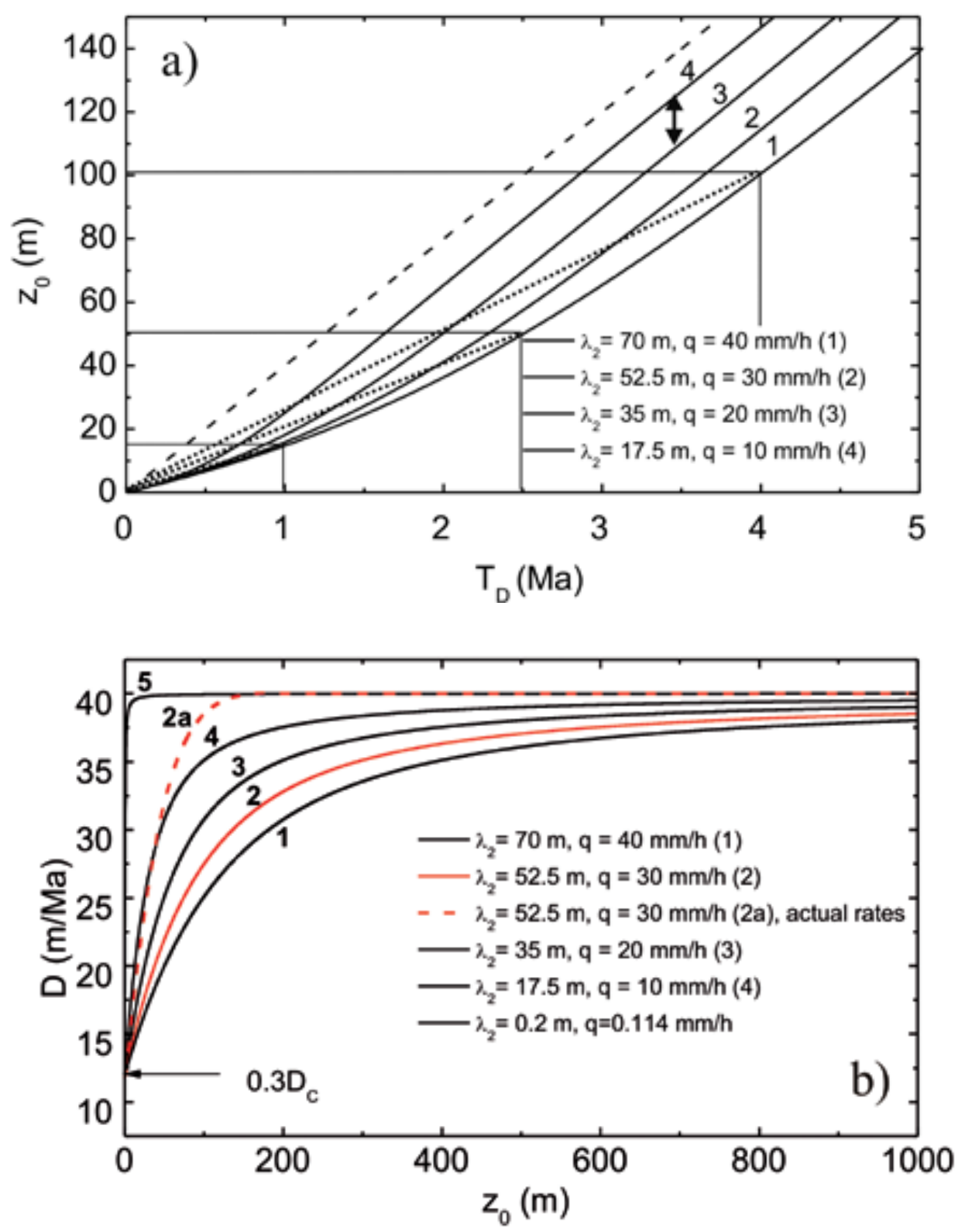

Fig. 5: a) The time dependence of removed thickness for several infiltration intensities. $I=1000 \mathrm{~mm} / \mathrm{y}, \mathrm{H}=100 \mathrm{mg} / \mathrm{L}, \rho=2.5 \mathrm{~g} / \mathrm{cm}^{3}, d=100 \mathrm{~cm}, N=2$. Dashed line show the "maximum denudation" rate which is $40 \mathrm{~m} / \mathrm{Ma}$. Dotted lines present the time averaged denudation rates (Eq.16). Double arrow demonstrates the difference between the denuded thicknesses which is kept in time due to the initial rate differences.

b) Dependence of average denudation rates on the removed thickness for the same scenarios as in Fig. 5a. Dashed line presents the actual surface lowering for $\lambda_{2}=52.5 \mathrm{~m}$. 


\section{CONCLUSION}

Denudation rate in a block with initially uniform porosity increases as the denudation proceeds and becomes maximum denudation (Eq.1), when the thickness of removed layer is about twice the typical saturation length. Initial differences arising from different saturation lengths remain imprinted in the surface.

If a soluble layer has a finite thickness, the average denudation rate increases with the thickness, i.e. denudation is more effective on thick rock layers.
The presented results are based on many assumptions which might not be valid. Nevertheless, it gives some theoretical validation of maximum denudation formulae and suggest some mechanisms that can cause irregularities in karst surface.

\section{REFERENCES}

Appelo, C. A. J. \& D. Postma, 1993: Geochemistry, groundwater and pollution. A.A. Balkema, xvi, 536 pp, Rotterdam; Brookfield, VT.

Bird, R. B., Stewart, W. E. \& E.N. Lightfoot, 2002: Transport phenomena. John Wiley \& Sons, Inc., xii, 895 p. pp, New York, Chichester.

Buhmann, D. \& W. Dreybrodt, 1985: The kinetics of calcite dissolution and precipitation in geologically relevant situations of karst areas.1. Open system.Chemical geology, 48, 189-211.

Corbel, J., 1959: Vitesse de l'erosion.- Zeitschrift fur Geomorphologie, 3, 1-2.

Dreybrodt, W., Gabrovšek, F. \& D. Romanov, 2005: Processes of speleogenesis: A modeling approach. Vol. 4, Carsologica, Založba ZRC, 375 pp, Ljubljana.

Dreybrodt, W., 1988: Processes in karst systems: physics, chemistry, and geology. Springer-Verlag, xii, 288 p. pp, Berlin; New York.

Eisenlohr, L., Meteva, K., Gabrovšek, F. \& W. Dreybrodt, 1999: The inhibiting action of intrinsic impurities in natural calcium carbonate minerals to their dissolution kinetics in aqueous $\mathrm{H}_{2} \mathrm{O}-\mathrm{CO}_{2}$ solutions.- Geochimica Et Cosmochimica Acta, 63, 989-1001.
Ford, D.C. \& P. Williams, 1989: Karst geomorphology and hydrology. Unwin Hyman, 601 pp, London.

Kaufmann, G. \& W. Dreybrodt, 2007: Calcite dissolutio $n$ kinetics in the system $\mathrm{CaCO}_{3}-\mathrm{H}_{2} \mathrm{O}-\mathrm{CaCO}_{3}$ at high undersaturation.- Geochimica Et Cosmochimica Acta, In Press.

White, W.B., 1984: Rate processes: chemical kinetics and karst landform development. In: La Fleur (Ed.): Groundwater as a geomorphic agent. Allen and Unwin, 227-248.

White, W. B., 1988: Geomorphology and hydrology of karst terrains. Oxford University Press, ix, 464 pp, New York. 
